\title{
Auguras da classe média
}

\author{
Livro relata a difícil experiência de quem está à procura de \\ emprego nos circuitos formados pelas grandes corporações \\ nos Estados Unidos. Escrito em estilo irônico, causa perple- \\ xidade no leitor ao mostrar que a crise do trabalho chegou \\ à classe média.
}

\section{por Pedro F. Bendassolli FGKEAESP}

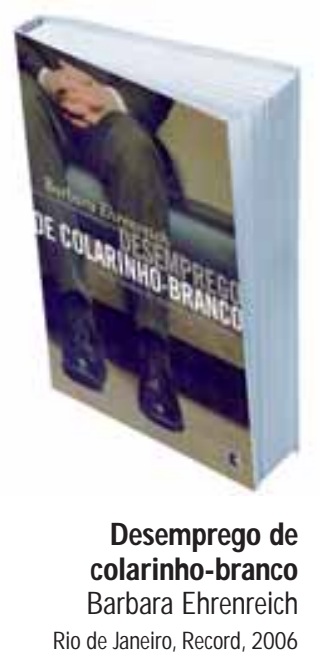

Em um condomínio fechado de classe média, típico enclave pós-moderno em que profissionais liberais usam suas reservas financeiras na busca de segurança, educação profissional dos filhos e uma vida higienicamente controlada, estoura uma revolução. Advogados, publicitários, médicos, arquitetos e professores universitários são enlevados por um líder que defende bandeiras "contra a sociedade". No centro da reivindicação, a liberdadeda classe média, soterrada mais e mais pelo al to valor das hipotecas de suas casas, das mensalidades escolares, das taxas de estacionamento (em frente à própria casa!) e do valor das prestações do automóvel.

Denominados de o "novo proletário" do século 21, a classe média põe-se à luta. Pelo menos é isso o que ocorre na ficção de J. G. Ballard, Terroristas do milênio (Companhia das Letras, 2005). Nela, 0 autor mostra uma verdadeira e surpreendente inversão da imagem comum que temos das classes sociais. Pelo legado marxista, temos conhecimento de que lutas de classe envolvem, ou envolviam, como atores uma parcela ínfima de pequenos burgueses endinheirados - os chamados capitalistas, detentores dos meios de pro- dução - de um lado e uma grande massa de despossuídos, ou semidespossuídos, de outro - denominado proletariado. No centro desse embate clássico, a luta por melhores condições de trabal ho, moradia, alimentação e conforto mínimo.

Em flagrante oposição, e distante 47 anos de Terroristas do milênio, a obra clássica do sociólogo norte-americano Wrigth Mills, W hite collar [Colarinhos-brancos] (1956), registrava a situação da então nova classe média norte-americana, que ficou conhecida como a dos white collars, ou colarinhos-brancos. A emergência dessa classe, na brilhante caracterização de Mills, era decorrentedeum fenômeno sem precedentes na história daquele país: a regressão da base de pequenos proprietários que compunham a matriz da economia e do capitalismo norte-americanos no século 19 ea necessidade da busca pelo emprego em grandes empresas.

No mesmo ano em que houve a publicação do White collars outra obra tornou-se clássica no que concerne ao estudo das transformações do trabalho. Trata-se do livro The organization man [0 homem-organização], de William Whyte (1956). N ele, o autor discute tese 
semelhante à de Mills, de que o espírito empreendedor que inspirou os momentos épicos do capitalismo estava sendo substituído por um humor conservador, materializado na busca pelo emprego. Os jovens de então preferiam compartilhar a premissa de que os objetivos da organização eram os mesmos que os seus do mesmo modo que a sua moral se confundia com a da organização.

É nesse clima de ascensão equeda da classe média pequeno-burguesa, penso eu, que devemos receber a nova obra da jornalista Barbara Ehrenreich, Iançada aqui como Desemprego de colarinhobranco, na qual ela explora a mobilidade descendente dos colarinhos-brancos na grande seara das megaempresas primeiro-mundistas. Os sinais de dificuldade, mesmo a miséria aberta, são cada vez mais comuns entre os profissionais bem escolarizados e "globalizados" da classe média norte-americana.

0 livro éinteressante tanto do ponto de vista do conteúdo como do método: a autora "fingiu" ser uma profissional em busca de emprego. Travestida com uma identidade profissional fictícia, aceitou o desafio de se passar por alguém necessitado de ajuda profissional para se recolocar. A obra revela-se então um diário das peripécias de um candidato a emprego, seus rituais, sofrimentos cotidianos, acertos, fracassos e, sobretudo, a agonia da espera.

Em cada capítulo Ehrenreich mostra como a indústria da recolocação é um negócio altamente lucrativo para seus profetas, masum calvário para aqueles que dela dependem. Sites de cadastramento de currículo, cursos de imersão, orientadores para melhoria da carreira, consultoria de orientação profissional, encontros ao estilo
"Alcoólatras Anônimos" para "conhecimento da própria personalidade" e "formação de redes" são estratégias comuns às quais recorre a classemédia desempregada para conseguir se reinserir.

Ao contrário da classe média-lúmpen e revolucionária de Ballard, Barbara Ehrenreich vêuma classe média fragilizada, suscetível e estranhamente subalterna. Quer dizer, não há na sua avaliação qualquer movimento, articulação ou crítica ao status quo, apenas o desejo de submissão e táticas solitárias de combate. Pessoalmente, gostei do livro de Ehrenreich e o recomendo, inclusive porque a autora, imune ao jargão corporativo corrente (ela é jornalista de profissão), parece conseguir analisá-lo com uma "ingenuidade" atraente. Uma espécie de The corporation em forma de livro.

Pedro F. Bendassolli

Doutor em Psicologia pela USP

Prof. do Departamento de Fundamentos Sociais e Jurídicos da Administração da FGV-EAESP

E-mail: pedro.bendassolli@fgv.br 